\title{
Akademik Örgütlerde Kindarlık Ölçeği’nin Geçerlik ve Güvenirliği: Bir Ölçek Geliştirme Çalışması*
}

\section{Mehmet KOÇYİĞIT**, Esra TEKEL***}

Öz: Akademik Örgütlerde Kindarlık Ölçeği’nin geçerlik ve güvenirlik çalışmalarının gerçekleştirilmesi bu araştırmanın amacıdır. Türkiye'de 51 farklı ildeki üniversitelerde görev yapmakta olan ve amaçlı örnekleme yöntemlerinden kolay ulaşılabilir örnekleme yolu ile seçilen 352 öğretim elemanı çalışmaya dahil edilmiştir. Yapı geçerliğinin sınanması için veriler üzerinde açımlayıcı faktör analizi ve sonrasında da güvenirlik analizleri uygulanmıştır. Bulgulara göre ölçek 34 madde ve altı faktörden oluşmaktadır. Ortaya çıkan yapı varyansın \%66.45'ini açıklamaktadır. Ölçeğin güvenirlik analizleri için Cronbach Alpha katsayısı yanında Guttman ve iki-yarı güvenirlik değerleri hesaplanmış ve ölçeğin geneli için Cronbach Alpha katsayısı .95 olarak bulunmuştur. Bulgular 1şı̆̆ında Akademik Örgütlerde Kindarlık Ölçeği’nin güvenilir ve geçerli bir ölçek olduğu söylenebilir.

Anahtar Kelimeler: Kin gütme, kindarlık, akademik örgütler, üniversite, ölçek geliştirme

\section{Validity and Reliability of the Scale for Grudge Bearing in Academic Organizations: A Scale Development Study}

Abstract: The purpose of this study is to carry out validity and reliability studies of The Scale for Grudge Bearing in Academic Organizations. 352 faculty members working in 51 different provinces of Turkey were included in the study using convenience sampling method. An exploratory factor analysis was applied on the data to test the construct validity, and reliability tests were carried out after that. According to the findings, the scale consists of 34 items and six factors. The resulting structure explains $66.45 \%$ of the variance. For the reliability analysis

\footnotetext{
${ }^{*} \mathrm{Bu}$ araştırma için Afyon Kocatepe Üniversitesi Sosyal ve Beşeri Bilimleri Bilimsel Araştırma ve Yayın Etiği Kurulu'nun Mayıs 2020 tarihli ve 2020/94 sayılı kararı ile etik izin alınmıştır.

** Dr. Öğr. Üyesi, Afyon Kocatepe Üniversitesi, Eğitim Fakültesi, Eğitim Bilimleri Bölümü, Email: mkocyigit@aku.edu.tr Orcid No: 0000-0002-1836-844X.

*** Dr. Öğr. Üyesi, Afyon Kocatepe Üniversitesi, Sandıklı Uygulamalı Bilimler Yüksekokulu, Email: etekel@aku.edu.tr, Orcid No: 0000-0003-4600-9900.
}

Gönderim:04.01.2021 Kabul:15.03.2021 Yayın:25.04.2021


of the scale, Cronbach's Alpha coefficient, Guttman and split-half reliability values were calculated. Cronbach's Alpha coefficient for the overall scale was found to be .95 . In the light of the findings, it can be said that The Scale for Grudge Bearing in Academic Organizations is a reliable and valid scale.

Keywords: Grudge, grudge bearing, academic organizations, university, scale development.

\section{Giriş}

Farklı yönlerine vurgu yapan tanımlarla karşılaşmak mümkün olsa da örgüt kısaca “toplumsal gereksinimlerin bir kesimini karşılamak üzere, önceden belirlenmiş amaçlara ulaştıracak işleri yapmak için güçlerini gönüllü ve düzenli olarak eşgüdümleyen insanlardan oluşan toplumsal açık bir sistem” (Başaran, 2000, s. 74) olarak tanımlanabilir. Örgütün bir amaca sahip olması, bu amaca ulaşma sürecinin, gerekli örgüt yapılanmasının, etkililiğin ve verimliliğinin de çalışılmasını beraberinde getirmiştir. 20. yüzyılın başlarında ortaya çıkan klasik örgüt teorisi çalışanlar, işin yönetimi ve örgütün nasıl yapılandırılması gerektiği gibi konularla ilgilenirken (Lunenburg ve Ornstein, 2013) 1920'lerin sonları ile 30'ların başları arasında devam eden Hawthorne araştırmalarında ise fiziksel çevre, çalışma şartları, saatleri ve dinlenme süreleri gibi değişkenlerin verimlilik üzerindeki etkisinin belirlenmesi hedeflenmiş ve örgütlerin sosyal yanını oluşturan insanın duygusal bir varlık olması dolayısıyla örgütlerin bir tür duygular sistemi olduğu kanısı ortaya çıkmıştır (Balyer, 2017; Lunenburg ve Ornstein, 2013). Dolayısıyla artık örgütteki bireylerin duygularının önemli olduğunun anlaşıldığı bu noktadan sonra bireyin davranış, duygu ve düşüncelerinin diğer kişilerin davranış ya da özelliklerinden nasıl etkilendiğini konu edinen sosyal psikoloji gibi bilim dalları bir grup ya da örgütün işleyiş ve verimliliğini etkileyen faktörleri incelerken sadece örgütsel süreçleri değil liderlik, yükleme, tutumlar, duygular ve etkileşim gibi bireyin kendi içindeki ve bireyler arası süreçleri de dikkate almaya başlamıştır (Cüceloğlu, 2008).

Yönetim alanındaki çalışmalar da davranışsal konulara büyük bir önem vermektedir çünkü bireylerin davranışları iş yaşantılarını da önemli ölçüde etkileyebilmektedir ve bu davranışlar yalnızca bireysel sonuçlar doğurmaktan öte içinde bulunulan gruplar üzerinde de ciddi olumlu veya olumsuz etkilere yol açabilmektedir (Çiçek ve Işık, 2018). Buna göre ruh halleri olumlu olan bireyler işlerine ve örgütle ilgili konulara daha ilgili olacaklardır. $\mathrm{Bu}$ da örgütün verimliliğini artırmada önemli bir yere sahiptir (Aydoğan, 2017). Ayrıca bireylerin risk almasını mümkün kılan ve örgütte yardımseverlik, açıklık, dürüstlük, sadakat gibi olumlu 
özelliklerin tesis edilmesine imkân veren örgütsel güven de örgütteki bireylerin psikolojilerinden etkilenen iyi bir iletişim ve diyalog ortamı, ödül, terfi ve performans değerlendirme gibi konularda güvene dayalı olma gibi unsurlar üzerine inşa edilmektedir (Memduhoğlu ve Zengin, 2017). Olumlu davranışların ortaya çıkmasında etkili olan olumlu duygular kadar olumsuz duygular da örgütler üzerinde önemli etkilere sahip olabilir. Örneğin olumsuz duygular örgütsel yaratıcılığın önünde bir engel olarak görülmektedir (Balay, 2017). Örgütün amaçlarını gerçekleştirmesini doğrudan etkilediği değerlendirilen örgüt iklimi, o örgütte bulunan birey ve grupların birbirleri ile ilişkilerinden ortaya çıkan bir durumdur ve olumlu bir iklimin örgütün amaçlarını gerçekleştirmesini kolaylaştıracağı düşünülmektedir (Balyer, 2017). Buradan hareketle olumsuz duyguların örgüt iklimini de olumsuz etkileyeceği söylenebilir. Ayrıca bunların yanında örgütsel sinizm, tükenmişlik, yabancılaşma gibi örgütsel kavramların bazıları da bir yönü ile olumsuz duygularla ilişkilendirilebilir. Kısaca örgütlerde davranış ve davranışı etkileyen olumlu ya da olumsuz duygular örgütlerin verimliliği yanında örgütsel güvenden iklime kadar çok çeşitli örgütsel çıtıtlarla da ilişkilendirilebilir. Kin, bahsedilen olumsuz duygulardan bir tanesidir ve örgütlerde örgütü oluşturan bireyler arasında oluşması muhtemel kindarlık da örgütlerde güven, yaratıcılık, iklim gibi hususlarda olumsuz etkiler oluşturabilir ve yine örgütlerde sinizm, tükenmişlik ya da yabancılaşma gibi olumsuz sonuçların ortaya çıkmasına sebep olabilir.

Kin, Türk Dil Kurumu Güncel Türkçe Sözlük’te (t.y.) "birine karşı duyulan öç alma isteği, garaz” olarak tanımlanmaktadır. Uluslararası literatürde İngilizce grudge kelimesi ile karşılanan kin, Oxford Learner's Dictionary'de (t.y.) geçmişte yaptıklarından dolayı birine karşı duyulan öfke ya da sevmeme duygusu şeklinde tanımlanmaktadır. Kindarlık ise sözlükte öç almak isteyen, kin tutan, kinci, kinli şeklinde tanımlanmıştır (Güncel Türkçe Sözlük, t.y.). Kindarlık bazen kin gütme ya da kin tutma şeklinde fiil olarak kullanılabilmektedir. Kin tutma, bireyin karşısındaki kişiye yönelik hissettiği gizli düşmanlık olarak tanımlanabilir. Bu noktada birey hissettiği gizli düşmanlık duygusuyla hareket etmekte ve bu durum örgütler için istenmeyen sonuçlar doğurabilmektedir (Kıral ve Nayır, 2019, s. 1).

\section{Akademi ve Kindarlık}

Türkiye'de üniversitelerde öğretim elemanı olmak için bazı ulusal sınavlardan belirli puanları almak, belirli diploma not ortalamalarını karşılamak ve kurumların düzenledikleri sözlü ya da yazılı bilimsel değerlendirme sınavlarından da başarılı olmak gerekmektedir. Ayrıca öğretim elemanı (araştırma görevlisi ya da öğretim görevlisi) dışında öğretim üyesi olmak isteyen bir kişi de doktora eğitimini başarıyla tamamlamalı ve alanına uygun şekilde kadro açan 
kurumlara başvurup kabul almalıdır. Doktora aşamasından sonra, öğretim üyesi olan kişi doktor öğretim üyesi unvanını almaktadır. Doçentlik unvanı alana kadar tüm öğretim elemanları belirli sürelerde yenilenen sözleşmelerle atanmakta ve görev yapmaktadırlar. Doçentlik unvanı almak isteyen bir öğretim üyesi (bazen bir öğretim elemanı da olabilmektedir) belirli yayın kriterlerini sağlayarak Üniversitelerarası Kurul'a başvurmalı ve dosyası kurulun belirlediği jüri tarafından başarılı bulunmalıdır. Doçent unvanını alan öğretim üyesi bu sefer de doçent kadrosunda çalışabilmek için bir üniversitenin açtığı kadroya başvurmak ve kabul almak durumundadır. Doçentlik unvanını aldıktan sonra, belirli bir süre şartını sağlamak kaydıyla gerekli yayın şartlarını da sağlayan öğretim üyesi, profesörlük unvanı almaya hak kazanmaktadır. Üniversitelerde profesör kadrosunda çalışabilmek için de herhangi bir üniversitede şartlarını sağladığı bir kadroya başvurmalı ve kabul almalıdır. Üniversitelerde doçent ve profesör kadrosuna atananlar diğer öğretim elemanları gibi sözleşme yenileme ve görev uzatma yapmak zorunda değildirler, daimî kadrolara atanırlar. Üniversitelerde rektörlük, dekanlık, müdürlük, bölüm başkanlığı ya da anabilim dalı başkanlığı gibi makamlara yapılacak atamalarda akademisyenlerin unvanları önem taşımaktadır. Tüm bu bahsedilen süreçler Yükseköğretim Kurulu tarafından çıkartılan 2547 sayılı Yükseköğretim Kanunu (1981), 2914 sayılı Yüksek Öğretim Personel Kanunu (1983) gibi kanunlar ve Öğretim Üyesi Dışındaki Öğretim Elemanı Kadrolarına Yapılacak Atamalarda Uygulanacak Merkezi Sınav ile Giriş Sınavlarına İlişkin Usul ve Esaslar Hakkında Yönetmelik (2018), Öğretim Üyeliğine Yükseltilme ve Atanma Yönetmeliği (2018) ve Üniversitelerde Akademik Teşkilât Yönetmeliği (1982) gibi yönetmeliklerde ifadesini bulmakta ve bunlara göre de yürütülmektedir. Bir akademisyenin çalışma hayatı boyunca bahsedilen bu süreçlerden ya da en azından bir kısmından geçmesi gerekmektedir ve bu süreçlerin neredeyse hepsinde, yüksek lisansa kabul için yapılan bilimsel değerlendirme sınavından profesörlük dosya değerlendirmesine kadar, akademisyen adayı ya da akademisyen, bazı jüri ya da komisyonlarca değerlendirmeye alınmaktadır. Bu jüri ya da komisyonlar çoğu zaman diğer akademisyenlerden oluşmaktadır. Jürilerin yaptığ değerlendirmeler akademisyen ya da akademisyen adayının hayatını derinden etkilemektedir. Aynı zamanda bu değerlendirmelerin çoğunda ve akademik hayatta rekabetin de oldukça güçlü olduğu noktalar bulunduğunu ifade etmek gerekmektedir (örneğin kadrolara yapılan başvurular ya da idari atamalar gibi). Değerlendirmeye tabi tutulmanın ve rekabetin önemli bir yer tuttuğu akademisyenlik, kariyerin her aşamasında, unvan derecesi farklı da olsa diğer meslektaşlarla karşı karşıya gelmeye ortam hazırlamaktadır. Bununla beraber bu süreçler bir taraftan merkezi olarak belirlenen atanma ve yükseltilme kriterlerinin alan bazlı özel ihtiyaçlara tam cevap 
verememesi ve puan odaklı yarışmacı bir sistem ortaya koyması, diğer taraftan da mevzuat ya da uygulamalardaki bazı boşlukların sübjektif değerlendirmelere ortam hazırlayabilmesi gibi iki farklı yönden değerlendirilebilir. Keza halihazırda akademik yükseltilme ve atanma kriterleri akademide en çok tartışılan konulardan birisidir (Karataş, Özen ve Gülnar, 2017). Literatürde konunun farklı yönleri ile ilgili olarak çalışmalar yapıldığg görülmektedir (Erdemir, 2019; Karataş Acer ve Güçlü, 2017; Karataş vd., 2017). Sonuçta böyle bir ortamda akademisyenin beklentilerinin karşılanmaması ve isteklerinin doyurulmaması ihtimal dahilindedir ve bu durum akademisyenin öfke duymasına ve bu öfkenin sürekli olmasına, başka bir deyişle akademisyenin kin tutmasına zemin hazırlayabilmektedir (Kıral ve Nayır, 2019). Akademik yükselmelerdeki engellemeler, bilimsel çalışmalara değer verilmemesi, akademisyenler arasındaki iletişim sorunları, nezaket dışı tutum ve davranışlar, bireysel kararlara saygısızlık ve gruplaşmalar, çıkar çatışmaları, kişisel rekabet, meslektaşın başarısını kabullenmeme, statü ve rol farklılıkları, akademisyenlerin unvan ya da idari görevlerinden kaynaklanan güçlerini kanıtlama gereksinimleri (Kasalak ve Aksu, 2016) gibi olumsuz durumların bu süreçlerde ortaya çıkma ihtimali de mevcuttur ve bunlar akademisyenlerde kindarlığın oluşmasında birer etken olabilecektir. Ek olarak bu ve benzeri durumlar ve akademisyenlerde oluşacak adaletsizlik algısı akademik örgütlerde de toksisiteye (Kasalak ve Aksu, 2016) ve uzun süreli olumsuz sonuçlara (Barclay ve Saldanha, 2016) sebep olabilirken akademisyenlerde de yabancılaşmaya (Yıldız ve Alıcı, 2019) ve öç alma, pişmanlık, suçluluk duygusu (Barclay ve Saldanha, 2016) gibi olumsuz duygulara neden olabilmektedir. Ayrica olumsuz duyguların örgütlerde yaratıcı düşünmeyi azaltma, tatminsizlik, düşük düzeyde duygusal bağlanma ve neticede işten ayrılma isteği gibi sonuçlar doğurabileceği de bilinmektedir (Andrieş, 2011; Balay, 2017).

Özetle üniversiteler gibi özgür, bilimsel ve tarafsız olması gereken akademik örgütlerde bile görülebilen kin tutma davranışı hem kin tutan bireyin hem de mağdur olan bireyin hayatını olumsuz etkilemekte ve telafisi mümkün olmayan sonuçlar doğurabilmektedir (Kıral ve Nayır, 2019, s.1). Burada şuna da dikkat çekmekte fayda vardır ki kin güden taraf mağdur taraf da olabilir ya da kendisine kin güdüldüğü için bir başkası tarafından mağdur edilmiş de olabilir. Başka bir deyişle kindarlık sergileyen taraf mağdur da olabilir, mağduriyeti ortaya çıkaran da olabilir.

Literatür incelendiğinde farklı alanlarda bu çalışmanın konusu ile doğrudan ya da dolaylı olarak ilgisi olabilecek çalışmaların olduğu görülebilir. Konu ile ilgili olabilecek birçok çalışma arasında örgütlerde pozitif ve negatif duygular (Andrieş, 2011), iş yerinde insan 
ilişkileri (Rotemberg, 1994), iş yerinde saldırganlık (Jawahar, 2002); hizmet sektöründe kin tutma (Bunker ve Ball, 2008) gibi konularda çalışmalar gösterilebilir. Yine eğitim alanında eğitim yönetiminde yönetsel kindarlık (Elma, 2019) ve yükseköğretim alanında da akademide mobbing (Erdemir, 2019) konulu çalışmalar konu ile ilgili çalışmalar arasında gösterilebilir. Fakat akademide kindarlık ile doğrudan ilgili bir çalışma Kıral ve Nayır (2019) tarafından yapılmıştır. İlgili çalışmada 2017-2018 akademik yılında bir devlet üniversitesindeki 13 akademisyenden nitel veriler toplanmış ve akademisyenlerin kin tutma davranışı araştırılmıştır. Araştırma sonucunda akademisyenlerin çoğunun kin tuttuğu ortaya konmuştur. Bu bağlamda bu çalışmanın amacı akademisyenlere dönük bir akademik örgütlerde kindarlık ölçeği geliştirmek ve geçerlik ve güvenirlik sınamalarını yapmaktır.

\section{Yöntem}

\section{Katılımcılar}

Akademik Örgütlerde Kindarlık Ölçeği’nin geçerlik ve güvenirlik çalışmaları için katılımcılar olasılık temelli olmayan amaçlı örnekleme yöntemlerinden kolay ulaşılabilir örnekleme yolu ile belirlenmiştir. Kolay ulaşılabilir örnekleme bir konu ile ilgili erken safha çalışmalarda ya da veri toplama araçlarının geçerliliğinin test edildiği çalışmalarda oldukça kullanışlıdır (Newby, 2014). Bu çalışmada da 2020 akademik yılı bahar döneminde Türkiye'nin 51 farklı ilinde yer alan üniversitelerde görev yapmakta olan ve kolay ulaşılabilir örnekleme yolu ile seçilen 352 öğretim elemanı çalışmaya dahil edilmiştir. Field (2009) faktör analizi için gerekli örneklem büyüklüğünden bahsederken 300 sayısının uygun bir örneklem büyüklüğü olduğunu ifade etmiştir. Dolayısıyla örneklem sayısının çalışma için yeterli olduğu söylenebilir. Örneklemin demografik özellikleri Tablo 1'de verilmiştir.

Tablo 1. Katılımcıların Demografik Özellikleri

\begin{tabular}{clcc}
\hline Değişken & \multicolumn{1}{c}{ Kategoriler } & $\boldsymbol{f}$ & $\boldsymbol{\%}$ \\
\hline \multirow{3}{*}{ Cinsiyet } & Kadın & 166 & 47.2 \\
& Erkek & 186 & 52.8 \\
& Toplam & 352 & 100 \\
\hline \multirow{3}{*}{ Unvan } & Araştırma Görevlisi & 79 & 22.4 \\
& Öğretim Görevlisi & 26 & 7.4 \\
& Doktor Öğretim Üyesi & 143 & 40.6 \\
& Doçent & 53 & 15.1 \\
& Profesör & 51 & 14.5 \\
& Toplam & 352 & 100 \\
\hline \multirow{2}{*}{ Kıdem } & 1-5 yıl & 55 & 15.6 \\
& 6-10 yıl & 137 & 38.9 \\
& 11-15 yıl & 43 & 12.2 \\
& 16 yıl ve üstü & 117 & 33.2 \\
& Toplam & 352 & 100 \\
\hline & Ege & 79 & 22.4 \\
& Marmara & 72 & 20.5 \\
\hline
\end{tabular}




\begin{tabular}{llcc}
\hline \multirow{3}{*}{ Bölge } & Karadeniz & 32 & 9.1 \\
& İç Anadolu & 89 & 25.3 \\
& Akdeniz & 24 & 6.8 \\
& Doğu Anadolu & 45 & 12.8 \\
& Güney Doğu Anadolu & 4 & 1.1 \\
& Belirtmedi & 7 & 2.0 \\
& Toplam & 352 & 100 \\
\hline
\end{tabular}

Tablo 1'de görüldüğü üzere katılımcıların \%47.2'si kadın, \%52.8'i erkektir. Katılımcıların \%22.4'ü araştırma görevlisi, \%7.4'ü öğretim görevlisi, \%40.6's1 doktor öğretim üyesi, \%15.1'i doçent ve \%14.5'i profesör unvanlarına sahiptir. Bunun yanında katılımcıların \%15.6'sı, 1-5 yıl, \%38.9'u 6-10 yı1, \%12.2'si 11-15 yıl ve \%33.2'si 16 yıl ve üzerinde çalışma yılına sahiptir. Son olarak Tablo 1'e göre katılımcıların \%22.4'ü Türkiye'nin coğrafi bölgelerinden Ege bölgesinde, \%20.5'i Marmara bölgesinde, \%9.1’i Karadeniz bölgesinde, \%25.3'ü İç Anadolu bölgesinde, \%6.8'i Akdeniz bölgesinde, \%12.8’i Doğu Anadolu bölgesinde, \%1.1'i Güneydoğu Anadolu bölgesinde bulunan bir üniversitede görev yapmaktadır ve katılımcıların \%2'si görev yapmakta olduğu coğrafi bölgeyi belirtmemiştir.

İşlem

Ölçeğin geliştirilmesi sürecinde DeVellis (2017) tarafından belirtilen ölçek geliştirmenin sekiz adımı takip edilmiştir. İlk olarak ölçülecek değişken (akademik örgütlerde kindarlık) belirlenmiştir. İkinci adım olarak bir madde havuzu oluşturulmuştur. Üçüncü adımda ölçek formatı beşli Likert olarak belirlenmiştir. Dördüncü adımda hazırlanan madde havuzu araştırmacılar dışında eğitim bilimleri alanında doktora derecesine sahip ve ölçek geliştirme ya da uyarlama deneyimi olan iki akademisyenin uzman görüşüne sunulmuş ve onlardan gelen dönütlere göre düzenlemeler yapılmıştır. Beşinci adımda doğrulama amaçlı benzer sorular da eklenmiş olarak ölçek taslağına son şekli verilmiştir. Altıncı adımda taslak ölçek araştırmaya katılmaya gönüllü 352 öğretim elemanından oluşan katılımcılara uygulanmıştır. Yedinci adımda elde edilen veriler üzerinde paket programla madde ayırt ediciliği, yapı geçerliği ve güvenirlik testleri yapılmıştır. Madde ayırt ediciliğini hesaplamak için madde-toplam ve madde-kalan korelasyonları Pearson korelasyonu kullanılarak hesaplanırken alt \% 27 ve üst \% 27'yi oluşturan grupların puan ortalamaları farkları bağımsız gruplar t-testi ile sınanmıştır. Taslak ölçeğin yapısını ortaya koymak amacıyla açımlayıcı faktör analizi uygulanmıştır. Ölçeğin iç güvenirliğini belirlemek amacıyla Cronbach's Alpha iç güvenirlik katsayısı, yarıya bölme yöntemi ve Guttman güvenirlik katsayıları kullanılmıştır. Sekizinci ve son adım olarak da analizler sonucu atılan-çıkarılan maddelerle ölçeğin son hali ortaya konulmuş, yap1 
geçerliğinde tespit edilen faktörler isimlendirilmiş ve ölçeğin adı "Akademik Örgütlerde Kindarlık Ölçeği”" olarak belirlenmiştir.

\section{Madde yazımı, Kapsam Geçerliği ve Derecelendirme}

Geliştirilen ölçeğin amacı akademik örgütlerde akademisyenlerin kin gütme düzeylerinin belirlenmesidir. Bu amaç doğrultusunda öncelikle ilgili literatür taranarak ve Kıral ve Nayır'ın (2019) çalışması incelenerek maddeler oluşturulmuştur. Taslak ölçek maddelerinin oluşturulmasından sonra ölçeğin kapsam geçerliği için araştırmacılar dışında eğitim bilimleri alanında doktora derecesine sahip ve ölçek geliştirme ya da uyarlama deneyimi olan iki akademisyenin uzman görüşüne başvurulmuştur. Başlangıçta 64 maddeden oluşan ölçeğe uzman görüşleri dahilinde iki madde daha eklenmiş ve böylece taslak ölçek 66 maddeden oluşmuştur. Katılımcılar maddeleri Hiç Katılmıyorum (1), Katılmıyorum (2), Kararsızım (3), Katılıyorum (4) ve Kesinlikle Katılıyorum (5) olmak üzere 5'li Likert aralığında değerlendirmişlerdir.

\section{Veri Toplama Süreci}

Veriler 2019-2020 akademik yılı bahar döneminde toplanmıştır. Türkiye'deki üniversitelerde görev yapmakta olan ve kolay ulaşılabilir örnekleme yolu ile seçilen 352 kişi araştırmaya online olarak katılmıştır. Araştırmaya katılım amacıyla oluşturulan bağlantıda araştırmanın amacı, veri gizliliğinin nasıl sağlanacağı ve sadece araştırma amacıyla kullanılacağı, verilerin nasıl doldurulması gerektiği, araştırmacılar hakkında kısa bilgiler ve ölçüm aracına yönelik talimatlar yer almıştır. Her katılımcının ölçeği sadece bir kez doldurabileceği şekilde sınırlandırma yapılarak bağlantı oluşturulmuştur. Katılımcıların veri toplama aracını tamamlaması yaklaşık 20 dakika sürmüştür.

\section{Etik Kurul Kararı}

Afyon Kocatepe Üniversitesi Sosyal ve Beşeri Bilimleri Bilimsel Araştırma ve Yayın Etiği Kurulu'nun Mayıs 2020 tarihli ve 2020/94 sayılı kararı ile araştırmanın etik açıdan sakıncalı olmadığına karar verilmiştir.

\section{Bulgular}

Bu bölümde taslak ölçeğin yapı geçerliği ve güvenirliği sınanmış ve elde edilen bulgular sunulmuştur. Yapı geçerliğinin sınanması için veriler üzerinde açımlayıcı faktör analizi uygulanmıştır. Yapı geçerliği sınanmadan önce madde analizleri yapılmış ve faktör analizinden sonra güvenirliğin sınanması için de Cronbach $\alpha$, iki yarı güvenirlik ve Guttman değerleri hesaplanmıştır. 


\section{Madde Ayırt Ediciliği}

Madde ayırt ediciliği analizleri kapsamında taslak ölçek üzerinde madde-toplam, madde-kalan analizleri ve \%27'lik alt-üst gruplar karşılaştırılması yapılmıştır.

\section{Madde-toplam korelasyonu}

Madde toplam analizinde her bir maddeden elde edilen puanlar ile ölçek genelinden elde edilen puanlar arasındaki korelasyon kat sayısı hesaplanmıştır. Sonuçlar Tablo 2'de sunulmuştur.

Tablo 2. Madde-Toplam Korelasyonu Değerleri

\begin{tabular}{|c|c|c|c|c|c|}
\hline Madde & $\mathbf{r}$ & Madde & $\mathbf{r}$ & Madde & $\mathbf{r}$ \\
\hline Madde 1 & $.557 *$ & Madde 23 & $.565 *$ & Madde 45 & $.500^{*}$ \\
\hline Madde 2 & $.723 *$ & Madde 24 & $.425^{*}$ & Madde 46 & $.476^{*}$ \\
\hline Madde 3 & $.661 *$ & Madde 25 & $.195 *$ & Madde 47 & .042 \\
\hline Madde 4 & $.553 *$ & Madde 26 & $.574 *$ & Madde 48 & .014 \\
\hline Madde 5 & $.530 *$ & Madde 27 & $.636^{*}$ & Madde 49 & $.192 *$ \\
\hline Madde 6 & $.615^{*}$ & Madde 28 & $.419 *$ & Madde 50 & .075 \\
\hline Madde 7 & $.579 *$ & Madde 29 & $.596 *$ & Madde 51 & $.388^{*}$ \\
\hline Madde 8 & $.556^{*}$ & Madde 30 & $.677^{*}$ & Madde 52 & $.727 *$ \\
\hline Madde 9 & $.656^{*}$ & Madde 31 & $.644^{*}$ & Madde 53 & $.572 *$ \\
\hline Madde 10 & $.722 *$ & Madde 32 & $.684^{*}$ & Madde 54 & $.620 *$ \\
\hline Madde 11 & $.713 *$ & Madde 33 & $.677 *$ & Madde 55 & $.653^{*}$ \\
\hline Madde 12 & $.541^{*}$ & Madde 34 & $.637^{*}$ & Madde 56 & $.567 *$ \\
\hline Madde 13 & $.482 *$ & Madde 35 & $.544 *$ & Madde 57 & $.527 *$ \\
\hline Madde 14 & $.744 *$ & Madde 36 & $.552 *$ & Madde 58 & .049 \\
\hline Madde 15 & $.673 *$ & Madde 37 & $.514 *$ & Madde 59 & $.527 *$ \\
\hline Madde 16 & $.601 *$ & Madde 38 & $.632 *$ & Madde 60 & $.607 *$ \\
\hline Madde 17 & $.737^{*}$ & Madde 39 & $.755^{*}$ & Madde 61 & $.620 *$ \\
\hline Madde 18 & $.516^{*}$ & Madde 40 & $.240^{*}$ & Madde 62 & $.556^{*}$ \\
\hline Madde 19 & $.518^{*}$ & Madde 41 & $.611^{*}$ & Madde 63 & $.640 *$ \\
\hline Madde 20 & $.403^{*}$ & Madde 42 & $.657 *$ & Madde 64 & $.569 *$ \\
\hline Madde 21 & $.277^{*}$ & Madde 43 & $.659 *$ & Madde 65 & $.544 *$ \\
\hline Madde 22 & $.686^{*}$ & Madde 44 & $.637 *$ & Madde 66 & $.547 *$ \\
\hline
\end{tabular}

Tablo 2'ye göre anlamlı bulunan korelasyon katsayıları .388 ile .755 arasında değişmektedir. Ölçeğin bütünü ile anlamlı ilişkisi olmayan madde 47, 48, 50 ve 58 ölçekten çıkartılmıştır. Bunun yanında ölçeğin bütünü ile ilişkisi anlamlı olmasına rağmen korelasyon katsayısı .30'un altında olan maddeler 21, 25, 40 ve 49 da ölçekten çıkartılmıştır. Madde toplam analizi sonucunda 66 maddeden 8 madde ölçekten çıkartılmış, madde kalan analizi 58 madde üzerinden devam etmiştir. 


\section{Madde-kalan korelasyonu}

Ölçekteki her bir maddenin değerinin ayrı ayrı ölçek toplamından çıkarılması ile elde edilen kalan değer ile çıkartılan madde arasındaki ilişkiye bakmak üzere madde kalan analizi yapılmıştır. Madde kalan değerlerini belirlemek için Pearson korelasyon analizi yapılmış, sonuçlar Tablo 3'te sunulmuştur. Tablo 3'e göre korelasyon katsayılarının tamamının anlamlı olduğu ve .362 ile .743 arasında değiştiği görülmüştür.

Tablo 3. Madde-Kalan Korelasyonu Analizi Sonuçları

\begin{tabular}{cccccc}
\hline Madde & $\mathbf{r}$ & Madde & $\mathbf{r}$ & Madde & $\mathbf{r}$ \\
\hline Madde 1 & $.541^{*}$ & Madde 22 & $.672^{*}$ & Madde 43 & $.656^{*}$ \\
Madde 2 & $.711^{*}$ & Madde 23 & $.542^{*}$ & Madde 44 & $.630^{*}$ \\
Madde 3 & $.641^{*}$ & Madde 24 & $.390^{*}$ & Madde 45 & $.493^{*}$ \\
Madde 4 & $.528^{*}$ & Madde 26 & $.559^{*}$ & Madde 46 & $.461^{*}$ \\
Madde 5 & $.500^{*}$ & Madde 27 & $.621^{*}$ & Madde 51 & $.362^{*}$ \\
Madde 6 & $.588^{*}$ & Madde 28 & $.388^{*}$ & Madde 52 & $.720^{*}$ \\
Madde 7 & $.566^{*}$ & Madde 29 & $.580^{*}$ & Madde 53 & $.547^{*}$ \\
Madde 8 & $.538^{*}$ & Madde 30 & $.668^{*}$ & Madde 54 & $.611^{*}$ \\
Madde 9 & $.632^{*}$ & Madde 31 & $.624^{*}$ & Madde 55 & $.639^{*}$ \\
Madde 10 & $.711^{*}$ & Madde 32 & $.676^{*}$ & Madde 56 & $.551^{*}$ \\
Madde 11 & $.696^{*}$ & Madde 33 & $.668^{*}$ & Madde 57 & $.509^{*}$ \\
Madde 12 & $.515^{*}$ & Madde 34 & $.622^{*}$ & Madde 59 & $.500^{*}$ \\
Madde 13 & $.455^{*}$ & Madde 35 & $.518^{*}$ & Madde 60 & $.600^{*}$ \\
Madde 14 & $.731^{*}$ & Madde 36 & $.532^{*}$ & Madde 61 & $.619 *$ \\
Madde 15 & $.652^{*}$ & Madde 37 & $.503^{*}$ & Madde 62 & $.549 *$ \\
Madde 16 & $.583^{*}$ & Madde 38 & $.621^{*}$ & Madde 63 & $.625^{*}$ \\
Madde 17 & $.726^{*}$ & Madde 39 & $.743^{*}$ & Madde 64 & $.560^{*}$ \\
Madde 18 & $.491^{*}$ & Madde 41 & $.596^{*}$ & Madde 65 & $.532^{*}$ \\
Madde 19 & $.501^{*}$ & Madde 42 & $.641^{*}$ & Madde 66 & $.535^{*}$ \\
Madde 20 & $.377^{*}$ & & & & \\
\hline & & & & \\
\hline
\end{tabular}

$* p<.001$

\section{\%27'lik alt-üst grupların karşılaştırılması}

Taslak formdaki 58 maddelik ölçekten elde edilen ham puanlar büyükten küçüğe sıralandığında alt \% 27 ve üst \% 27'yi oluşturan grupların puan ortalamaları bağımsız gruplar t-testi ile karşılaştırılarak maddelerin ayırt edicilik güçleri elde edilmiş ve Tablo 4'te sunulmuştur. Tablo 4'e göre her maddenin istenilen düzeyde ayırt edici ( $p<.001)$ olduğu görülmüştür. 
Tablo 4. Ölçek Maddelerinin Ayırt Ediciliklerine İlişkin Bağımsız Gruplar t-Testi Sonuçları

\begin{tabular}{|c|c|c|c|c|c|}
\hline Madde & $\mathbf{t}$ & Madde & $\mathbf{t}$ & Madde & $\mathbf{t}$ \\
\hline Madde 1 & $39.519 *$ & Madde 22 & $40.504 *$ & Madde 43 & $18.084 *$ \\
\hline Madde 2 & $44.943 *$ & Madde 23 & $44.568^{*}$ & Madde 44 & $18.728^{*}$ \\
\hline Madde 3 & $48.143^{*}$ & Madde 24 & $42.605^{*}$ & Madde 45 & $18.336^{*}$ \\
\hline Madde 4 & $54.420 *$ & Madde 26 & $24.978 *$ & Madde 46 & $24.368^{*}$ \\
\hline Madde 5 & $64.526 *$ & Madde 27 & $42.598 *$ & Madde 51 & $42.758 *$ \\
\hline Madde 6 & $58.487 *$ & Madde 28 & $27.054 *$ & Madde 52 & $37.986 *$ \\
\hline Madde 7 & $32.219 *$ & Madde 29 & $25.485^{*}$ & Madde 53 & $40.509 *$ \\
\hline Madde 8 & $36.397 *$ & Madde 30 & $31.536^{*}$ & Madde 54 & $21.413^{*}$ \\
\hline Madde 9 & $48.551 *$ & Madde 31 & $50.609 *$ & Madde 55 & $41.083 *$ \\
\hline Madde 10 & $43.410 *$ & Madde 32 & $23.445^{*}$ & Madde 56 & $40.506^{*}$ \\
\hline Madde 11 & $41.671 *$ & Madde 33 & $39.794 *$ & Madde 57 & $40.924 *$ \\
\hline Madde 12 & $38.948 *$ & Madde 34 & $42.253 *$ & Madde 59 & $40.907 *$ \\
\hline Madde 13 & $32.848 *$ & Madde 35 & $33.641 *$ & Madde 60 & $20.332 *$ \\
\hline Madde 14 & $45.349 *$ & Madde 36 & $41.134 *$ & Madde 61 & $23.001 *$ \\
\hline Madde 15 & $50.352 *$ & Madde 37 & $45.669 *$ & Madde 62 & $23.275^{*}$ \\
\hline Madde 16 & $43.507 *$ & Madde 38 & $29.064^{*}$ & Madde 63 & $38.989 *$ \\
\hline Madde 17 & $43.849 *$ & Madde 39 & $40.776 *$ & Madde 64 & $25.983 *$ \\
\hline Madde 18 & $48.200 *$ & Madde 41 & $40.560 *$ & Madde 65 & $20.183^{*}$ \\
\hline Madde 19 & $38.033 *$ & Madde 42 & $42.080 *$ & Madde 66 & $23.158 *$ \\
\hline Madde 20 & $41.074 *$ & & & & \\
\hline
\end{tabular}

\section{Ölçeğin Yapı Geçerliği: Açımlayıcı faktör analizi}

Ölçeğin yapısını keşfetmek için veriler üzerinde açımlayıcı faktör analizi yapılmıştır. Açımlayıcı faktör analizi için örneklem yeterliliği Kaiser-Meyer-Olkin (KMO) örneklem yeterlilik kriteri ve veri yapısı Bartlett's küresellik testi ile test edilmiştir. Faktör analizine uygun olması için KMO katsayısının 0.5'in üzerinde olması gerekmektedir (Leech, Barrett, ve Morgan, 2013; Şencan, 2005). Test sonucunda KMO katsayıs1 .94 ( $\mathrm{p}=.00)$ olarak bulunmuştur. Bartlett's küresellik testi katsayısı ise $7686.046(\mathrm{p}=.00)$ olarak hesaplanmıştır. Buradan hareketle katılımcı sayısının yeterli ve veri yapısının faktör çıkarmaya uygun olduğu söylenebilir. Açımlayıcı faktör analizi sonucunda elde edilen faktör yükleri ve yapının açıkladığ 1 toplam varyans oranları Tablo 5 'te sunulmuştur. 
Tablo 5. Açımlayıcı Faktör Analizi Sonucuna Göre Faktör Yükleri ve Açılanan Varyans Değerleri

\begin{tabular}{|c|c|c|c|c|c|c|c|c|}
\hline Madde Numarası & $\begin{array}{c}\text { Faktör } 1 \\
*(\% 17.769)\end{array}$ & $\begin{array}{c}\text { Faktör } 2 \\
(\% 15.869)\end{array}$ & $\begin{array}{c}\text { Faktör 3 } \\
(\% 10.352)\end{array}$ & $\begin{array}{l}\text { Faktör } 4 \\
(\% 8.023)\end{array}$ & $\begin{array}{l}\text { Faktör } 5 \\
(\% 7.701)\end{array}$ & $\begin{array}{c}\text { Faktör } 6 \\
(\% 6.737)\end{array}$ & $\mathbf{X}$ & SS \\
\hline Madde 14 & .772 & & & & & & 2.90 & 1.35 \\
\hline Madde 10 & .760 & & & & & & 2.97 & 1.31 \\
\hline Madde 2 & .706 & & & & & & 3.25 & 1.28 \\
\hline Madde 1 & .689 & & & & & & 2.66 & 1.27 \\
\hline Madde 3 & .683 & & & & & & 3.09 & 1.38 \\
\hline Madde 22 & 677 & & & & & & 3.00 & 1.25 \\
\hline Madde 11 & .651 & & & & & & 2.88 & 1.29 \\
\hline Madde 7 & .633 & & & & & & 3.89 & 1.17 \\
\hline Madde 39 & .605 & & & & & & 2.84 & 1.25 \\
\hline Madde 9 & .604 & & & & & & 2.84 & 1.37 \\
\hline Madde 52 & .511 & & & & & & 2.71 & 1.15 \\
\hline Madde 64 & & .827 & & & & & 4.09 & .84 \\
\hline Madde 65 & & .812 & & & & & 4.29 & .84 \\
\hline Madde 62 & & .794 & & & & & 4.20 & .87 \\
\hline Madde 61 & & .732 & & & & & 4.34 & .68 \\
\hline Madde 63 & & .747 & & & & & 3.86 & 1.07 \\
\hline Madde 60 & & .719 & & & & & 4.35 & .68 \\
\hline Madde 66 & & .650 & & & & & 4.17 & .91 \\
\hline Madde 36 & & & .824 & & & & 2.18 & 1.19 \\
\hline Madde 34 & & & .736 & & & & 2.95 & 1.31 \\
\hline Madde 37 & & & .734 & & & & 3.36 & 1.18 \\
\hline Madde 59 & & & .690 & & & & 2.72 & 1.17 \\
\hline Madde 35 & & & .666 & & & & 2.07 & 1.15 \\
\hline Madde 56 & & & & .767 & & & 2.81 & 1.22 \\
\hline Madde 55 & & & & .688 & & & 3.28 & 1.14 \\
\hline Madde 41 & & & & .618 & & & 2.72 & 1.21 \\
\hline Madde 28 & & & & & .808 & & 2.00 & 1.02 \\
\hline Madde 5 & & & & & .759 & & 2.49 & 1.27 \\
\hline Madde 6 & & & & & .665 & & 2.51 & 1.30 \\
\hline Madde 42 & & & & & .549 & & 2.73 & 1.22 \\
\hline Madde 46 & & & & & & .717 & 4.14 & .96 \\
\hline Madde 45 & & & & & & .697 & 4.47 & .77 \\
\hline Madde 43 & & & & & & .607 & 4.26 & .80 \\
\hline Madde 44 & & & & & & .570 & 4.23 & .81 \\
\hline
\end{tabular}

Faktör analizi gerçekleştirilirken faktör yükü .40 'ın altında olan ya da birden fazla faktörde yüksek faktör yüküne sahip olan ve faktör yükleri arasında .10'dan az fark bulunan 
(Field, 2009) 4, 8, 12, 13, 15, 16, 17, 18, 19, 20, 23, 24, 26, 27, 29, 30, 31, 32, 33, 38, 51, 53, 54 ve 57. maddeler olmak üzere toplam 24 madde ölçekten çıkarılmıştır. Tablo 5'e göre ölçek altı faktörden oluşmakta ve faktörler toplam varyansın \%66.452'sini açıklamaktadır. Sosyal bilimlerde \%40 ila \%60 arasındaki varyans oranlarının yeterli kabul edildiği (Tavşancıl, 2006) göz önünde bulundurulduğunda elde edilen açıklanan toplam varyans oranının yeterli olduğu görülmüştür.

Bunun yanında Field (2009) örneklem 200'den büyük olduğunda faktör yapısını belirlerken scree plot kullanılmasını tavsiye etmektedir. Bu çalışmada da örneklem 200'den büyük olduğu için scree plot dikkate alınmıştır. Grafik incelendiğinde 6 faktörden sonra kırılmaların yatay bir seyir izlediği görülmüştür (bkz. Şekil 1). Analizler neticesinde ölçeğin altı faktörlü bir yapıya sahip olduğu kanısına varılmıştır.

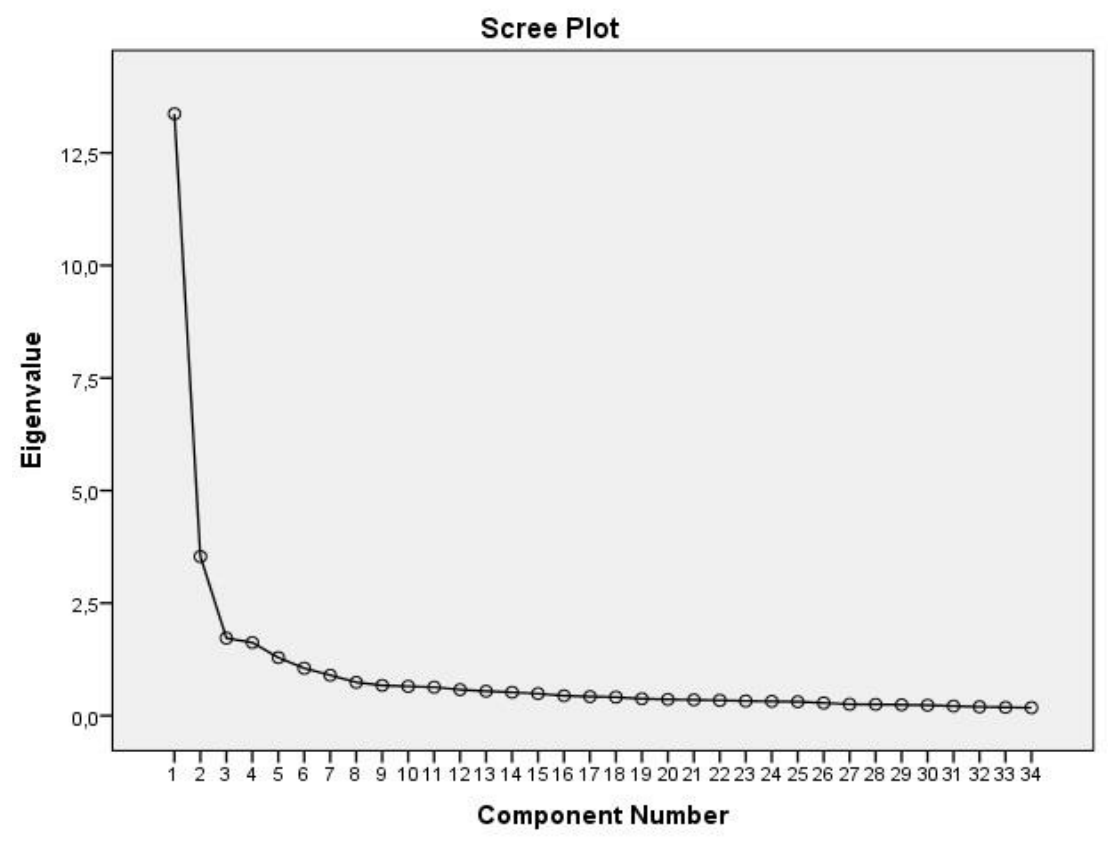

Şekil 1. Açımlayıcı faktör analizi scree plot grafiğgi

Elde edilen faktörler incelendiğinde belirlenen faktör isimleri ve faktörler altında yer alan maddeler Tablo 6'da sunulmuştur. 
Tablo 6. Faktörler ve Faktörlere Ait Maddeler

\begin{tabular}{|c|c|c|}
\hline FAKTÖR & MADDE NO & IFADELER \\
\hline \multirow{11}{*}{ 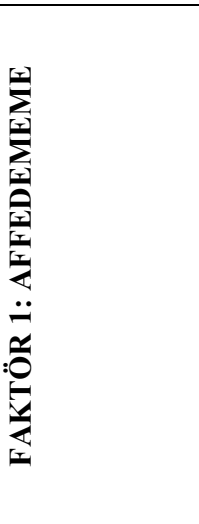 } & Madde 14 & $\begin{array}{l}\text { Akademik yükselmelerde bana yaşattıklarından dolayı bazı akademisyenleri hiç } \\
\text { affedemiyorum. }\end{array}$ \\
\hline & Madde 10 & Akademik hayatta mobbing/yıldırmaya çokça uğradığımı düşünüyorum. \\
\hline & Madde 2 & Meslektaşlarımın bana yaşattıkları olumsuzlukları unutamıyorum. \\
\hline & Madde 1 & Akademik yükselmelerde bilinçli olarak önümün kesildiğini düşünüyorum. \\
\hline & Madde 3 & Hocalarımın bana yaşattıkları olumsuzlukları unutamıyorum. \\
\hline & Madde 22 & Akademide bana adil davranılmadığını düşünüyorum. \\
\hline & Madde 11 & $\begin{array}{l}\text { Yaşadıklarım yüzünden artık en ufak akademik engellenmeye/zorluğa tahammül } \\
\text { edemiyorum. }\end{array}$ \\
\hline & Madde 7 & Yaşadığım engellenmeleri/zorlukları hak etmediğimi düşünüyorum. \\
\hline & Madde 39 & Sık sık hakkımın yendiği fikri kafamda dolaşıyor. \\
\hline & Madde 9 & $\begin{array}{l}\text { Lisansüstü eğitimim döneminde bana yaşattıklarından dolayı bazı akademisyenleri hiç } \\
\text { affedemiyorum. }\end{array}$ \\
\hline & Madde 52 & Akademide başarılarımın görmezden gelindiğini düşünüyorum. \\
\hline \multirow{7}{*}{ 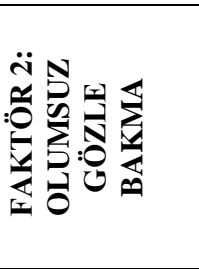 } & Madde 64 & Bazı akademisyenlerin şımarıkça tavırlar sergilediğini düşünüyorum. \\
\hline & Madde 65 & Bazı akademisyenler bence unvanlarını taşıyamıyor. \\
\hline & Madde 62 & Bazı akademisyenlerin yükseldikçe daha fütursuz tavırlar sergilediklerine inanıyorum. \\
\hline & Madde 61 & Bazı akademisyenlerin saygısız olduğunu düşünüyorum. \\
\hline & Madde 63 & Akademide esaslı bir ders alması gereken kişiler olduğunu düşünüyorum. \\
\hline & Madde 60 & Bazı akademisyenlerin bencil olduğunu düşünüyorum. \\
\hline & Madde 66 & Elimde olsa akademide esaslı bir düzenleme yapmak isterdim. \\
\hline \multirow{5}{*}{ 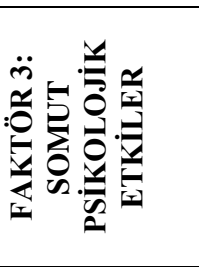 } & Madde 36 & $\begin{array}{l}\text { Akademik hayatta yaşadığım olumsuzluklardan dolayı psikosomatik rahatsızlıklar } \\
\text { yasadım/yaşyorum. }\end{array}$ \\
\hline & Madde 34 & $\begin{array}{l}\text { Akademik hayatta yaşadığım olumsuzluklardan dolayı psikolojik sıkıntılar } \\
\text { yaşadım/yaşıyorum }\end{array}$ \\
\hline & Madde $37 *$ & Akademik hayatta yaşadığım olumsuzluklar beni pek etkilemedi. \\
\hline & Madde 59 & Diğer akademisyenlerden kaynaklı sorunlardan yaşadığım gerginliği evime yansıtırım. \\
\hline & Madde 35 & Akademik hayatta yaşadığım olumsuzluklardan dolayı dişlerimi sıkma alışkanlığı başladı. \\
\hline \multirow{3}{*}{ 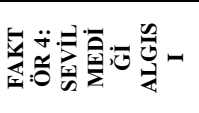 } & Madde 56 & Kurumda beni sevmeyen bir kitle olduğunu düşünüyorum. \\
\hline & Madde 55 & Çoğu zaman arkamdan konuşulduğunu düşünüyorum. \\
\hline & Madde 41 & İşlerimi en doğru şekilde yapmaya çalıştığım için sevilmediğimi düşünüyorum. \\
\hline \multirow{4}{*}{ 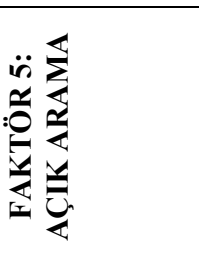 } & Madde 28 & $\begin{array}{l}\text { Bir akademisyene kızdığımda akademik yayınlarını karıştırırım ve negatif bir gözle } \\
\text { incelerim. }\end{array}$ \\
\hline & Madde 5 & $\begin{array}{l}\text { Bana kötülük yapanların akademik hayatlarında neler yaptıklarını elimde olmadan takip } \\
\text { ediyorum. }\end{array}$ \\
\hline & Madde 6 & $\begin{array}{l}\text { Belli bir noktaya geldiğimde, bana yapılanların hesabını sorumlulara sormayı hayal } \\
\text { ederim/ederdim. }\end{array}$ \\
\hline & Madde 42 & Bana haksızlık yapan akademisyenlerin yükselmesini kaldıramıyorum. \\
\hline \multirow{4}{*}{ 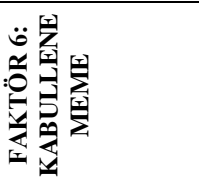 } & Madde 46 & $\begin{array}{l}\text { Hasbelkader akademide bulunan bazı insanların en azından daha da yükselmemesi } \\
\text { gerektiğine inanıyorum. }\end{array}$ \\
\hline & Madde 45 & Bazı insanlar akademiye hiç girmemeliydi diye düşünüyorum. \\
\hline & Madde 43 & Bazı akademisyenlerin dürüst olmadığına inanıyorum. \\
\hline & Madde 44 & Bazı akademisyenlerin başkalarının başarılarını çekemediğini düşünüyorum. \\
\hline
\end{tabular}

\section{Güvenirlik Analizleri}

Ölçeğin güvenirliği, Cronbach Alpha katsayısı, iki yarı testi güvenirlik yöntemi ve Guttman katsayısı ile incelenmiş ve faktörlere ve ölçeğin tamamına ilişkin katsayılar Tablo 7'de sunulmuştur. 
Tablo 7. Akademik Kin Gütme Ölçeği'nin Faktörlerine ve Toplamına Ait Cronbach Alpha, İki Yarı Güvenirliği ve Guttman Katsayıları

\begin{tabular}{lccccc}
\hline Faktörler & n & Madde sayısı & $\begin{array}{c}\text { Cronbach } \\
\text { Alpha }\end{array}$ & Íki yarı & Guttman \\
\hline Faktör 1: Affedememe & 352 & 11 & .930 & .925 & .907 \\
Faktör 2: Olumsuz gözle bakma & 352 & 7 & .910 & .895 & .883 \\
Faktör 3: Somut psikolojik etkiler & 352 & 5 & .865 & .822 & .768 \\
Faktör 4: Sevilmediği algısı & 352 & 3 & .789 & .784 & .721 \\
Faktör 5: Açık arama & 352 & 4 & .794 & .774 & .772 \\
Faktör 6: Kabullenememe & 352 & 4 & .839 & .754 & .753 \\
Toplam & 352 & 34 & .950 & .803 & .803 \\
\hline
\end{tabular}

Ölçeğin Cronbach Alpha katsayısı alt boyutlarda .789 ile .930 arasında iken ölçeğin geneli için .950 olarak bulunmuştur. Güvenirlik analizlerinde güvenirlik katsayısının .90 civarında olmasının "mükemmel”; .80 "çok iyi” ve .70 civarında olmasının da "yeterli" olarak kabul edildiği (Kline, 2011) göz önünde bulundurulduğunda ölçeğin güvenirliğinin mükemmel olduğu söylenebilir. Bunun yanında yarıya bölme analizi sonucunda faktörlere ait iki yarı değerleri .925 ile .754 arasında değişirken Guttman katsayısının .907 ile .721 arasında değiştiği görülmüştür.

Ölçek faktörlerinin kendi aralarında ve ölçeğin tamamıyla olan ilişkilerin belirlenmesi amacıyla yapılan Pearson korelasyon analizi sonuçları Tablo 8'de sunulmuştur.

Tablo 8. Faktörler arası Pearson korelasyonları

\begin{tabular}{lccccccc}
\hline & Faktör 1 & Faktör 2 & Faktör 3 & Faktör 4 & Faktör 5 & Faktör 6 & Toplam \\
\hline Faktör 1 & 1 & & & & & & \\
Faktör 2 & $.504^{*}$ & 1 & & & & & \\
Faktör 3 & $.643^{*}$ & $.353^{*}$ & 1 & & & & \\
Faktör 4 & $.616^{*}$ & $.503^{*}$ & $.430^{*}$ & 1 & & \\
Faktör 5 & $.566^{*}$ & $.418^{*}$ & $.442^{*}$ & $.424^{*}$ & 1 & & \\
Faktör 6 & $.480^{*}$ & $.707^{*}$ & $.350^{*}$ & $.472^{*}$ & $.418^{*}$ & 1 & $.679^{*}$ \\
Toplam & $.917^{*}$ & $.720^{*}$ & $.737^{*}$ & $.722^{*}$ & $.698^{*}$ & & \\
$* p<.001$ & & & & & &
\end{tabular}

Tablo 8'e göre faktörlerin birbirleri ile ve ölçeğin bütünüyle olan ilişkilerinin tümünün anlamlı olduğu $(\mathrm{p}<.001)$ ve korelasyon katsayılarının .350 ile .917 arasında değiştiği görülmektedir.

\section{Tartışma ve Sonuç}

$\mathrm{Bu}$ araştırmanın amacı, üniversitelerde akademisyenlerin kindarlık düzeylerini belirlemek için Akademik Örgütlerde Kindarlık Ölçeği’nin geliştirilmesidir. Yapılan geçerlik ve güvenirlik analizleri sonucunda 34 madde ve altı faktörden oluşan 5'li Likert tipinde geçerli ve güvenilir bir ölçek elde edilmiştir. Yapılan açımlayıcı faktör analizi sonucuna göre ortaya çıkan altı faktör şu şekilde isimlendirilmiştir: İlk faktöre affedememe, ikinci faktöre olumsuz gözle bakma, üçüncü faktöre somut psikolojik etkiler, dördüncü faktöre sevilmediği algisl, 
beşinci faktöre açık arama ve altıncı faktöre de kabullenememe adı verilmiştir. Ölçekten alınabilecek maksimum puan 170, minimum puan ise 34'tür. Yüksek puan ortalamas1 akademisyenlerin kindarlık düzeylerinin yüksek olduğu anlamına gelmektedir. Affedememe boyutunda yüksek ortalamaya sahip bir akademisyen geçmişte yaşadığı veya kısmen hala yaşamaya devam ettiği bazı olayları unutamamakta ve hatırladıkça bu olayların faillerine karşı da kin duyma eğilimine girmektedir. Olumsuz gözle bakma faktöründe kişi diğer meslektaşlarının olumsuz tavır ve davranışlarını görmekte ve bunlar aracılı̆̆ değerlendirmektedir. Somut psikolojik etkiler faktöründe yüksek puan ortalamasına sahip bir akademisyen meslektaşlarından kaynaklı ya da onlarla ilişkilendirdiği tecrübelerinden dolayı somut psikolojik/psikosomatik etkilere maruz kalmaktadır. Dördüncü faktörde yüksek ortalamaya sahip bir kişi kendisinin sevilmediği algısına sahiptir. Beşinci faktörde yüksek puan ortalamasına sahip bir akademisyenin olumsuz tecrübeleri ile ilişkilendirdiği akademisyenlerin akademik ya da hayatlarındaki diğer edimlerini takip edip (hatta belki bir gün hesap sorabilecek duruma gelme ihtimalini de dikkate alarak) bir açık arama faaliyetine giriştiği söylenebilir. Kabullenememe boyutunda yüksek bir ortalamaya sahip bir kişi ise bazı meslektaşlarının takdirlerini, sözlerini hatta akademideki varlıklarını kabullenememe noktasındadır. Faktörler incelendiğinde kin ve kindarlık tanımı yapılırken belirtilen öç alma isteği, gizli düşmanlık gütme, garaz, sevmeme gibi duyguları yansıttıkları ve bunların birleşerek kindarlık oluşturacağı görülebilmektedir. Dolayısıyla ölçek genelinde alınan yüksek puan ortalaması tüm bu bahsedilen faktörlerin bileşkesi olarak akademisyenin muhataplarına karşı kindarlık düzeyi olarak yorumlanabilir. Ölçekten alınan puan ortalamaları değerlendirildiğinde ölçeğin beşli derecelendirmeye sahip olduğu dikkate alınarak 1-1.79 ortalama çok düşük, 1.80-2.59 düşük, 2.60-3.39 orta, 3.40-4.19 yüksek ve 4.20-5.00 arası ortalama puanlar ise çok yüksek düzeyde kindarlık olarak yorumlanabilir.

Kariyer yolculuğu boyunca defalarca sınavlarla, jürilerle ve yükselmelerle karşı karşıya gelen akademisyenlerin, deneyimledikleri olumsuz olaylar nedeniyle kin gütmeleri olasıdır. $\mathrm{Bu}$ olumsuz deneyimler hem bireyleri olumsuz etkileyebilmekte (Kıral ve Nayır, 2019) hem de örgüt içinde adaletsizlik algısıyla birlikte toksisite (Kasalak ve Aksu, 2016) gibi olumsuz sonuçlara (Barclay ve Saldanha, 2016), akademisyenlerde yabancılaşmaya (Yıldız ve Alıcı, 2019) ve öç alma, pişmanlık, suçluluk duygusu (Barclay ve Saldanha, 2016) gibi olumsuz duygulara neden olabilmektedir. Ayrıca kin gütme gibi olumsuz duyguların örgütlerde yaratıcı düşünmeyi azaltma, tatminsizlik, düşük düzeyde duygusal bağlanma ve neticede işten ayrılma isteği gibi sonuçlar doğurabileceği de bilinmektedir (Andrieş, 2011; Balay, 2017). Bu duygular 
örgütsel güveni ve örgüt iklimini olumsuz etkileyebileceği gibi örgütsel sinizm, tükenmişlik, yabancılaşma gibi örgütsel kavramların bazılarıyla da bir yönü ile ilişkilendirilebilir.

İlgili literatürde konu ile doğrudan ilgili çok fazla çalışma tespit edilememiş olsa da Kıral ve Nayır (2019) yaptıkları çalışmada kin tutma konusunda akademisyenlerle nitel görüşmeler gerçekleştirmiş ve ulaştıkları sonuçlarda akademisyenlerin kin tutmayı duygu ve davranış olarak iki şekilde algıladıklarını ortaya koymuşlardır. Bu araştırmada ölçek maddeleri yazılırken bu ayrım dikkate alınmıştır. Bahsedilen çalışmada katılımcıların çoğunun kin tuttuğu ve bunu kendilerine ya da karşı tarafa bir şekilde yansıttıkları ortaya konulmuştur. Bu çalışmada ortaya çıkan faktörlerde de somut psikolojik etkiler ve sevilmediği algısı faktörlerinde kişinin daha çok kendi ile ilgili duygu, düşünce, deneyim ve davranışları, diğer faktörlerde ise karşı tarafa dönük durumları ele alınmıştır. Aynı çalışmada kin tutmaya ilişkin bireysel ve örgütsel sebepler ortaya konmuştur. Bu çalışmada da ölçek maddeleri oluşturulurken bu iki yönün de dikkate alınmasına gayret edilmiştir. Adı geçen çalışmada konu ile ilgili geçerli ve güvenilir bir ölçek geliştirilmesi gerekliliği de vurgulanmıştır. Bu çalışmanın çıktılarından bir tanesi de bu gereksinimin karşılanması olmuştur.

Politika yapıcılar ve akademik örgütlerde yönetici konumunda bulunanlar için dikkate alınması gereken önemli bir kavram olan akademik örgütlerde kindarlık hakkında yapılacak çalışmalarda bu ölçek kullanılabilir. Gelecekteki araştırmalar için doğrulayıcı faktör analizi yapılarak ölçek yapısının tekrar test edilmesi önerilebilir. Bunun yanında unvan, çalışılan üniversite türü (devlet- vakıf) ya da farklı demografik değişkenlere göre akademik örgütlerdeki kindarlık düzeyleri ölçülebilir. Ayrıca akademik örgütlerde kindarlık ile örgütsel bağlılık, örgütsel toksisite, örgütsel adanmışlık, örgütsel güven, örgüt iklimi ve kültürü gibi örgütsel değişkenlerin ilişkisi incelenebilir. Akademik örgütlerde kindarlık ile öznel iyi oluş, performans, iş doyumu gibi bireysel değişkenlerin de ilişkisi incelenebilir. Sonuç olarak Akademik Örgütlerde Kindarlık Ölçeği hem bireysel hem örgütsel değişkenlerin kindarlık düzeyi ile ilişkilerini ortaya çıkarma noktasında hem araştırmacılar hem de uygulayıcılar tarafından kullanılabilecek geçerli ve güvenilir bir ölçektir.

\section{Makalenin Bilimdeki Konumu}

Eğitim Bilimleri/Eğitim Yönetimi

\section{Makalenin Bilimdeki Özgünlüğü}

Bu çalışmada akademik örgütlerde ortaya çıkabileceği literatürdeki farklı çalışmalarda da belirtilen kindarlık davranışı ile ilgili geçerli ve güvenilir bir ölçek geliştirilmeye 
çalışılmıştır. Örgütlerde davranışı olumsuz yönde etkileyebilecek bu konunun çalışılmasının ve akademik örgütler özelinde bir ölçek ortaya konmasının ilgili literatüre katkı yapacağı düşünülmektedir.

\section{Kaynaklar}

Andrieș, A. M. (2011). Positive and negative emotions within the organizational context. Global Journal of Human Social Science, 11 (9), 26-40.

Aydoğan, İ. (2017). Örgütsel vatandaşlık davranışı. H. B. Memduhoğlu, \& K. Yılmaz içinde, Yönetimde yeni yaklaşımlar (s. 390-424). Ankara: Pegem Akademi.

Balay, R. (2017). Yönetimde yaratıcılık. H. B. Memduhoğlu, \& K. Yılmaz içinde, Yönetimde yeni yaklaşımlar (s. 74-99). Ankara: Pegem Akademi.

Balyer, A. (2017). Ĕgitim yönetiminde yeni yaklaşımlar. Ankara: Anı Yayıncılık.

Barclay, L. J., \& Saldanha, M. F. (2016). Facilitating forgiveness in organizational contexts: Exploring the injustice gap, emotions, and expressive writing interventions. Journal of Business Ethics, 137(4), 699-720.

Başaran, İ. E. (2000). Yönetim (3 b.). Ankara: Feryal Matbaası.

Bunker, M. P., \& Ball, D. (2008). Causes and consequences of grudge-holding in service relationships. Journal of Services Marketing, 22(1), 37-47.

Cüceloğlu, D. (2008). İnsan ve davranışı (17 b.). İstanbul: Remzi Kitabevi.

Çiçek, B. ve Işık, M. (2018). Örgütsel dedikodu ve intikam. 6. Örgütsel Davranış Kongresi Bildiriler Kitabı 2-3 Kasım 2018 / Isparta

DeVellis, R. F. (2017). Scale development: Theory and applications (4.b.). The USA: Sage.

Elma, C. (2019). Öğretmenlerin okul yöneticilerinin kindarlık davranışlarına ilişkin algıları. Eurasian Journal of Educational Research, 19 (83), 57-80.

Erdemir, B. (2019). Türkiye'de akademide mobbing ve çözüm önerileri: Lisansüstü tezlerin içerik analizi. Yükseköğretim Dergisi, 9 (2), 213-233.

Field, A. (2009). Discovering statistics using SPSS. (3rd ed.). Dubai: Sage

Güncel Türkçe Sözlük. (t.y.). Kin. 15 Aralık 2020 tarihinde erişilmiştir, https://sozluk.gov.tr/. Jawahar, I. (2002). A model of organizational justice and workplace aggression. Journal of Management, 28 (6), 811-834.

Karataş Acer, E., \& Güçlü, N. (2017). Türkiye'de yükseköğretimin genişlemesi: Gerekçeler ve ortaya çıkan sorunlar. Yüksekögretim Dergisi, 7 (1), 28-38. 
Karataş, T., Özen, Ş., \& Gülnar, E. (2017). Akademisyenlerin kariyer basamakları ve yükseltme ölçütlerine ilişkin görüşleri. Yükseköğretim Dergisi, 7 (2), 82-93.

Kasalak, G., \& Aksu, M. B. (2016). Örgütler nasıl zehirlenir? Öğretim elemanlarının örgütsel toksisite algıları. Hacettepe Üniversitesi Eğitim Fakültesi Dergisi, 31(4), 676-694.

Kıral, B., \& Nayır, F. (2019). Akademisyen görüşlerine göre akademide kin tutma. Yüksekögretim Dergisi, 9(3), 1-13.

Kline, R. B. (2011). Principles and practice of structural equation modelling. New York: Guildford Publications Press.

Leech, N., Barrett, K., \& Morgan, G. A. (2013). SPSS for intermediate statistics: Use and interpretation. New Jersey: Lawrence Erlbaum Associates.

Lunenburg, F. C., \& Ornstein, A. C. (2013). Eğitim yönetimi. (G. Arastaman, Çev.) Ankara: Nobel Yayın.

Memduhoğlu, H. B., \& Zengin, M. (2017). Örgütsel güven. H. B. Memduhoğlu, \& K. Yılmaz içinde, Yönetimde yeni yaklaşımlar (s. 350-365). Ankara: Pegem Akademi.

Newby, P. (2014). Research methods for education (2. b.). London, UK: Routledge.

Oxford Learner's Dictionary. (t.y.). Grudge. 20 Aralık 2020'de erişilmiştir, https://www.oxfordlearnersdictionaries.com/definition/english/grudge_1?q=grudge.

Rotemberg, J. J. (1994). Human relations in the workplace. Journal of Political Economy, 102 (4), 684-717.

Şencan, H. (2005). Sosyal ve davranışsal ölçümlerde güvenilirlik ve geçerlilik. Ankara: Seçkin yayıncıl1k

Tavşancıl, E. (2006). Tutumların ölçülmesi ve SPSS ile veri analizi (3. basım). Ankara: Nobel.

Yıldız, S., \& Alıcı, D. (2019). Akademisyenliğe yabancılaşma ölçeğinin geliştirilmesi: Geçerlik ve güvenirlik çalışması. Yüksekögretim Dergisi, 9(1), 49-58.

Yükseköğretim Kurulu. (1981). 2547 sayılı yükseköğretim kanunu. 7 Kasım 2020 tarihinde erişilmiştir, https://www.mevzuat.gov.tr/MevzuatMetin/1.5.2547.pdf.

Yükseköğretim Kurulu. (1982). Üniversitelerde akademik teşkilât yönetmeliği. 20 Kasım 2020 tarihinde erişilmiştir, https://www.yok.gov.tr/kurumsal/mevzuat.

Yükseköğretim Kurulu. (1983). 2914 sayılı yüksek öğretim personel kanunu. 7 Kasım 2020 tarihinde erişilmiştir, https://www.mevzuat.gov.tr/MevzuatMetin/1.5.2914.pdf.

Yükseköğretim Kurulu. (2018). Öğretim üyesi dışındaki öğretim elemanı kadrolarına yapılacak atamalarda uygulanacak merkezi sınav ile giriş sınavlarına ilişkin usul ve esaslar 
hakkında yönetmelik, öğretim üyeliğine yükseltilme ve atanma yönetmeliğii. 8 Kasım 2020 tarihinde erişilmiştir, https://www.yok.gov.tr/kurumsal/mevzuat.

\section{Summary}

\section{Statement of Problem}

Facing exams, juries, and promotions repeatedly throughout their career, academics are likely to bear grudges due to the negative events they experience. These negative experiences can both negatively affect individuals (Kıral \& Nayır, 2019) and lead to long-term negative consequences (Barclay \& Saldanha, 2016) such as toxicity with the perception of injustice (Kasalak \& Aksu, 2016), alienation among academics (Y1ldız \& Alıc1, 2019) and negative emotions such as revenge, regret, and guilt (Barclay \& Saldanha, 2016). In addition, it is known that negative emotions such as bearing a grudge can lead to consequences such as reduced creative thinking in organizations, dissatisfaction, low level of emotional attachment and eventually the desire to quit (Andrieş, 2011; Balay, 2017). These feelings may affect the organizational climate negatively and may also be associated with some of the organizational concepts such as organizational cynicism, burnout, and alienation.

\section{Method}

In the process of developing the scale, eight steps of scale development specified by DeVellis (2017) were followed. First, the variable to be measured (grudge bearing in academic organizations) was determined. As a second step, an item pool was created. In the third step, the scale format was determined as five-point Likert. The item pool prepared in the fourth step was presented to the expert opinion of two academicians with doctorate degrees in educational sciences and experience in scale development or adaptation, and arrangements were made according to their feedback. In the fifth step, the draft of the scale was finalized by adding similar questions for verification purposes. In the sixth step, the draft scale was applied to a sample of 352 academics who volunteered to participate in the study. Item discrimination, construct validity and reliability tests were performed on the data obtained in the seventh step. Item-total and item-remainder correlations were calculated using Pearson correlation to calculate item discrimination. Exploratory factor analysis was applied to reveal the structure of the draft scale. Cronbach's Alpha internal reliability coefficient, split-half and Guttman reliability coefficients were used to determine the internal reliability of the scale. As the eighth and last step, the final version of the scale was put forward after some items were removed as a result of the analyses, the factors determined in the construct validity were named and the 
name of the scale was determined as the "Scale for Grudge Bearing in Academic Organizations".

\section{Findings}

As a result of the exploratory factor analysis performed after the item analyses, the KMO coefficient was found to be $.94(\mathrm{p}=.000)$. Bartlett's test coefficient was calculated as 7686.046 $(\mathrm{p}=.000)$. According to the analysis result, it consists of six factors and the factors explain $66.452 \%$ of the total variance. While the Cronbach Alpha coefficient of the scale was between .789 and .930 in the sub-dimensions, it was found as .950 for the overall scale. In addition, as a result of the split-half analysis, the values of the factors varied between .925 and .754, while Guttman analysis results varied between .907 and .721. It was determined that the correlations of the factors with each other and with the whole scale were significant $(p<.001)$ and the correlation coefficients ranged from .350 to .917 .

\section{Discussion and Conclusion}

As a result of the validity and reliability analyses, a valid and reliable 5-point Likert type scale consisting of 34 items and six factors was obtained. The six factors that emerged according to the results of the exploratory factor analysis were named as follows: The first factor was called inability to forgive, the second factor was called having a cynical view, the third factor was called concrete psychological effects, the fourth factor was named perception of being disliked, the fifth factor was called seeking others' vulnerabilities, and the sixth factor was named failure to accept. The maximum score that can be obtained from the scale is 170 , and the minimum score is 34 . High score average means that academics' level of grudge bearing is high. When the mean scores from the scale are evaluated, considering that the scale has a five-point rating, average scores are interpreted as 1-1.79 very low, 1.80-2.59 low, 2.60-3.39 medium, 3.40-4.19 high, and 4.20-5.00 very high level of grudge bearing. This scale can be used in studies about grudge bearing in academic organizations, which is an important concept that should be taken into account for policy makers and managers in academic organizations. For future research, it may be suggested to re-test the scale structure by performing a confirmatory factor analysis. In addition, the level of grudge in academic organizations can be measured according to different demographic variables. In addition, the relationship between grudge bearing and organizational variables such as organizational commitment, organizational toxicity, organizational climate, trust and culture can be examined in academic organizations. 
YYÜ Eğitim Fakültesi Dergisi (YYU Journal of Education Faculty), 2021; 18(1)547-568, http://efdergi.yyu.edu.tr,

doi:10.33711/ yyuefd.919429 Araştırma Makalesi

ISSN: $1305-2020$

\section{Etik Kurul Kararı}

Afyon Kocatepe Üniversitesi Sosyal ve Beşeri Bilimleri Bilimsel Araştırma ve Yayın Etiği Kurulu’nun Mayıs 2020 tarihli ve 2020/94 sayılı kararı gereği çalışma açısından Sosyal ve Beşeri Etik Kuralları ve İlkeleri çerçevesinde herhangi bir sakınca olmadığına karar verilmiştir. 